\title{
Load Flow Analysis of Dhaka Grid Using PSAT and ETAP and Performance Comparison with PGCB Data
}

\author{
Anas Abdullah Alvi and Mohammad Abdul Mannan
}

\begin{abstract}
This paper deals with a load flow simulation of existing Dhaka Grid Circle of Bangladesh National Grid by using Power System Analysis Toolbox (PSAT) which is a free and open source software of MATLAB Simulink and Electrical Transient and Analysis Program (ETAP) software designed for simulation, operation, and automation of generation, distribution, and industrial power systems. All the data used to simulate were collected from Power Grid Company of Bangladesh (PGCB) and Load flow analysis was carried out using Newton Raphson method and simulated results were compared with PGCB Base Case Data. The network considered to simulate has 71 buses (400, 230 and $132 \mathrm{kV}$ ), 135 interconnecting lines, 32 generators, 47 loads and only 4 shunt capacitors as per the Dhaka grid circle system. Regarding the maximum demand of the load centers, total 5,525 MW load is connected in this system and the average grid generation in September, 2018 was 10,919.57 MW, though only 5988 MW of the total generation is enlisted in the Dhaka grid circle.
\end{abstract}

Keywords-PSAT, ETAP, PGCB, HVDC, SVC, Load Flow

\section{INTRODUCTION}

All across the earth, the use of power system is uninterruptedly extending in size and growing in complexity. To cope with the flow of this expansion, the necessity for various system study, understanding and analyzing is much essential today than ever earlier. As Bangladesh is a developing country, so with the industrial growths in our country, the power system kept on increasing day by day. In such circumstances, load flow analysis may help the continuous assessment of current performance of the power system and analyzing the effectiveness of alternative plans for system expansion to meet raising load demand. Load flow analysis is focused with explaining the operating condition of an entire power system, by which we mean a network of generators, transmission lines, distribution lines and loads that could represent an area as small as a municipality or as large as several states. Considering certain known quantities-like the amount of power generated and consumed at different locations, load flow analysis permits one to determine other

\section{Anas Abdullah Alvi \\ American International University-Bangladesh \\ Dhaka, Bangladesh \\ anasalvimoto@gmail.com}

Mohammad Abdul Mannan

American International University-Bangladesh

Dhaka, Bangladesh

mdmannan@aiub.edu quantities. The most predominant of these quantities are the voltages at locations throughout the transmission system, which, for alternating current (AC) consists of both active and reactive power, phase angle or both magnitude and time element and following in each line [1], [2]. Load flow analysis are of great significance in planning and executing by designing the future expansion of power systems as well as in determining the best operation of existing systems [3], [4]. There was a time when it was a challenge to simulate and examine the load flow study of power system. But with the invention of modern technologies and introduction of computer aided load flow analysis, it is much simpler and reliable to accomplish these operations. Now-a-days different types of free simulation software are accessible online for load flow analysis. Among them PSAT, ETAP, MATPOWER, UWPFLOW etc. are noteworthy. Different circumstances need different techniques and algorithms used by the different software.

In this paper, a simulation model of electrical network system for Dhaka Grid circle is developed and the performance of this grid circle is analyzed. The simulation model has been developed by using the PSAT software which is a highly reliable free Power System Analysis toolbox for MATLAB Simulink as well as EPAT software which is a high impact commercial software used worldwide for the design, simulation, operation, and automation of generation, distribution, and industrial power systems. The total network consists of 71 buses $(400,230$ and $132 \mathrm{kV}), 135$ interconnecting lines, 32 generators, 47 loads and only 4 shunt capacitors as per the Dhaka grid circle system. The load flow study can be done by using the developed simulation model. To justify the developed simulation model the output of this software has been observed and compare with PGCB data of 20 September, 2018. On that day the generation is $11,623 \mathrm{MW}$ which is largest generation till now on 20 September 2018. In the existing model of PGCB, only the real values are provided in the PGCB website but in this paper that model was simulated using the two software PSAT and ETAP and load flow was obtained so that it can be improved in the future as well as if a new load or generator is introduced in the system, the real data can be measured very easily and accurately.

The paper is arranged in the following order: Section II describes about the simulation software, PSAT and ETAP briefly. Section III gives us the overall idea of the network for performing the simulation. Section IV compares the simulation results and performance of the software with that of the PGCB base case data. Lastly, Section V consists of the findings and conclusion. 


\section{ABOUT THE SOFTWARE}

\section{A. About PSAT}

PSAT is a comparatively brand new and up to date software (developed around 2004-2005) appointing the outstanding matrix-oriented computation techniques of MATLAB. This toolbox (MATLAB) or software-package is designed for control \& electric power system analysis. To grant flexibility to the user, it utilizes Simulink library as a graphical tool, which allows drawing of pictorial or schematic blocks to represent different components of a power system [5]. One distinctive point about PSAT is that, it can also run in GNU/ Octave environment- free software for performing numerical experiments using a language that is mostly compatible with MATLAB. It also reflects as one of the active FOSS (Free and Open-Source Software) projects for power systems [6]. Apart from fundamental power flow analysis, PSAT proposes various other static/dynamic analyses like CPF (Continuation Power Flow), OPF (Optimal Power Flow), Small-signal stability analysis, Time-domain simulations etc. For the simulation design of this work, only the power flow feature is explored. Newton-Raphson (NR) method, Runge-Kutta method, Fast decoupled methods (both BX and XB), Simple robust method are the available algorithmic options provided by PSAT to conduct power flow analysis. Both theoretically and practically Newton-Raphson (NR) algorithm converges faster to the solutions than the others, which is why we applied it to our system.PSAT allocates a set of parameters, consisting of the corresponding state variables, to each component. After the standard models (inter-related non-linear differential equations) are all established, Jacobians are formed in a common function. As soon as the necessary functions are organized, the iterative process begins and it continues until the best results regarding the tolerance limits are found. The results are output as a static report and further conversion into other formats can also be done.

\section{B. About ETAP}

ETAP is a full fetched electrical engineering software invented by Operation Technology Inc. (OTI) which specializes in the analysis, simulation, monitoring, control, optimization, and automation of electrical power systems. Starting from modeling to operation, everything related to power system enterprise is offered by the compact suite of ETAP. An excellent interface for performing severe analysis on electrical power systems is one of the special characteristics of ETAP. Not only that, it can also perform Electrical Transient analysis accurately. It also includes the integration of utility software such as Microsoft Excel. The ETAP software is designed with an excellent human friendly interface which is very easy to understand. The user manual which comes with it is also written in a very simple and easy manner which is efficient in solving a problem encountered during simulation. The toolbars of ETAP are arranged in a very organized way based on their respective functions. This arrangement comes in handy while designing a single line diagram. Different types of analysis can be performed by using the respective study modes such as Load Flow,
Unbalanced Load Flow, ANSI Short Circuit Analysis, Motor Starting Analysis, Harmonic Analysis, Transient Analysis, Star Protection Coordination, Optimal Load Flow, Reliability Analysis, Optimal Capacitor Placement, DC Load Flow, DC Short Circuit Analysis and Battery Sizing Analysis. [7]

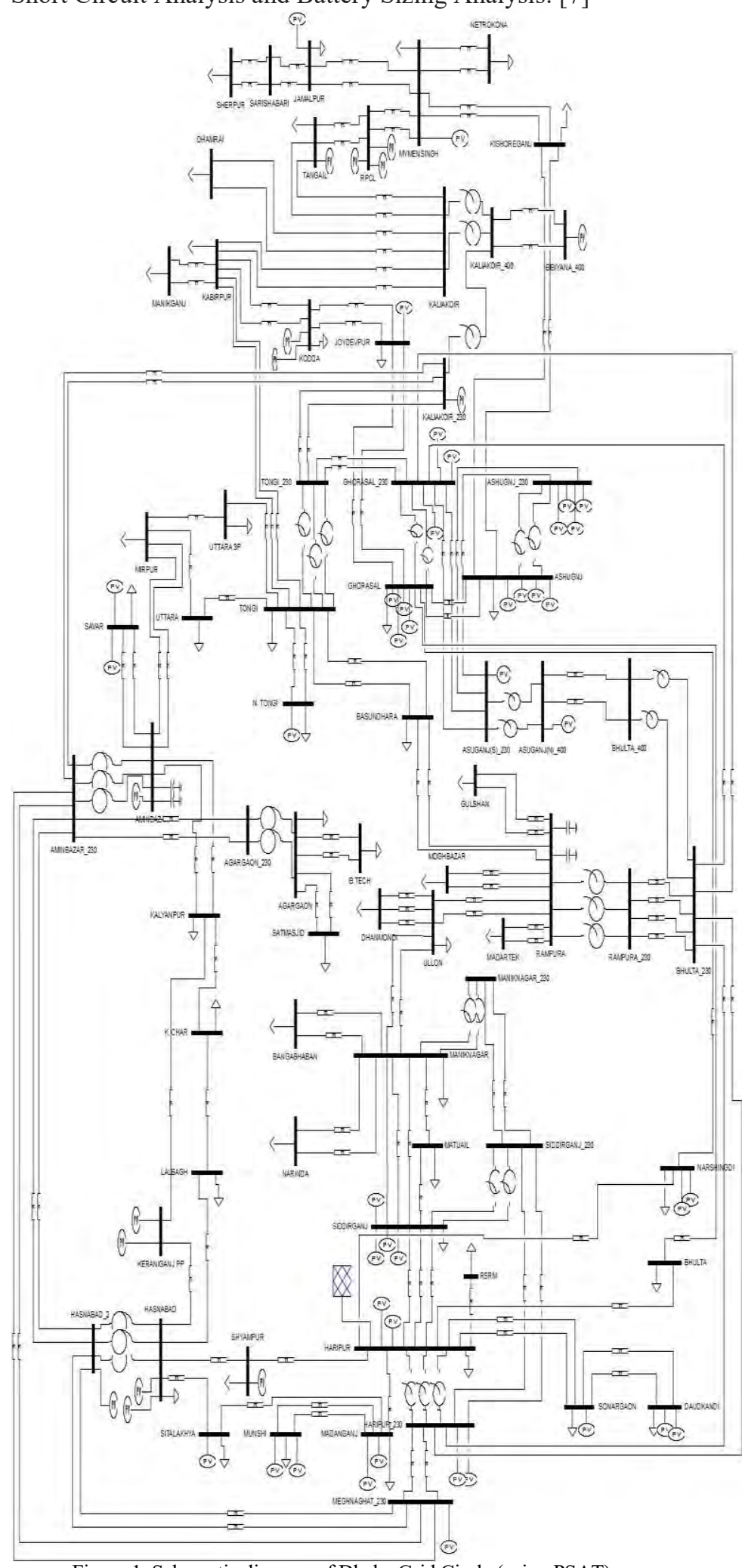

Figure 1. Schematic diagram of Dhaka Grid Circle (using PSAT) 


\section{OVERALl SYSTEM TAKEN UNDER CONSIDERATION}

Bangladesh has a very large distribution network with over 128 grid substations and total transmission line of around $6,251.234 \mathrm{~km}$ among which generating stations of $11 \mathrm{kV}, 11.5$ $\mathrm{kV}$ or $15.75 \mathrm{kV}$ are present. These are then stepped up to 400 $\mathrm{kV}, 230 \mathrm{kV}$ or $132 \mathrm{kV}$ and transmission lines are also designed as such. These are then stepped down in the substations and supplied to the required users.

The general block diagram of the Power System of Bangladesh is given below in figure 2:

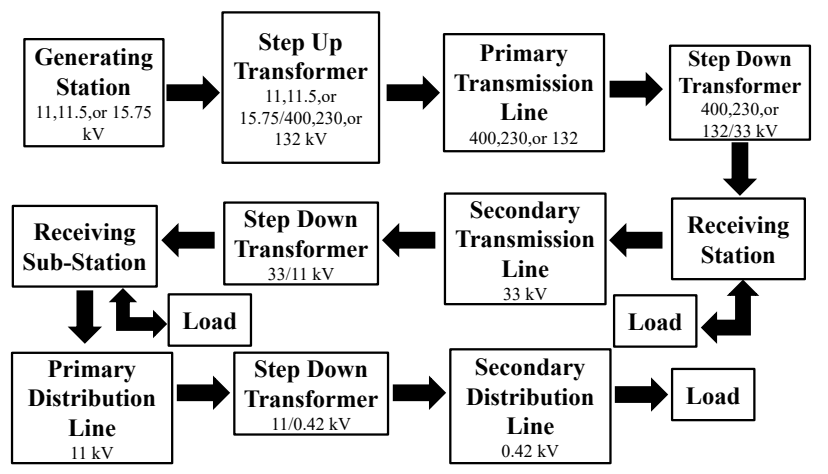

Figure 2. Block Diagram of Bangladesh Power System

The highest grid generation is 11,623 MW till now on 20 September 2018. The system was considered for the day (20 September 2018). Regarding the maximum demand of the load centers, total 5,525 MW load is connected in this system and the average grid generation in September, 2018 was 10,919.57 MW, though only $5988 \mathrm{MW}$ of the total generation is enlisted in the Dhaka grid circle.[8,9] Here, HARIPUR is defined as the slack bus for simulating the system under consideration. The lines are modeled with the $\pi$ - model for cables depicted in PSAT library. The network we are considering to simulate has 71 buses $(400,230$ and $132 \mathrm{kV}), 135$ interconnecting lines, 32 generators, 47 loads and only 4 shunt capacitors as per the Dhaka grid circle system are modeled with PSAT in figure 1 and ETAP in figure 3.

In the software PSAT and ETAP, HARIPUR is considered for defining the slack bus of our system and the model used in the transmission lines are considered $\pi$ - model for cable as shown in the PSAT library and cable for the ETAP library. Table I demonstrates all the working generators along with their bus connections. Table II shows the parameters considered for the line conductors. Even though the parameters in PSAT such as per unit (p.u.) data (resistance, reactance and susceptance) for each line were taken from the table, parameters such as the specifications for other components like generators or transformers were kept as the default settings.

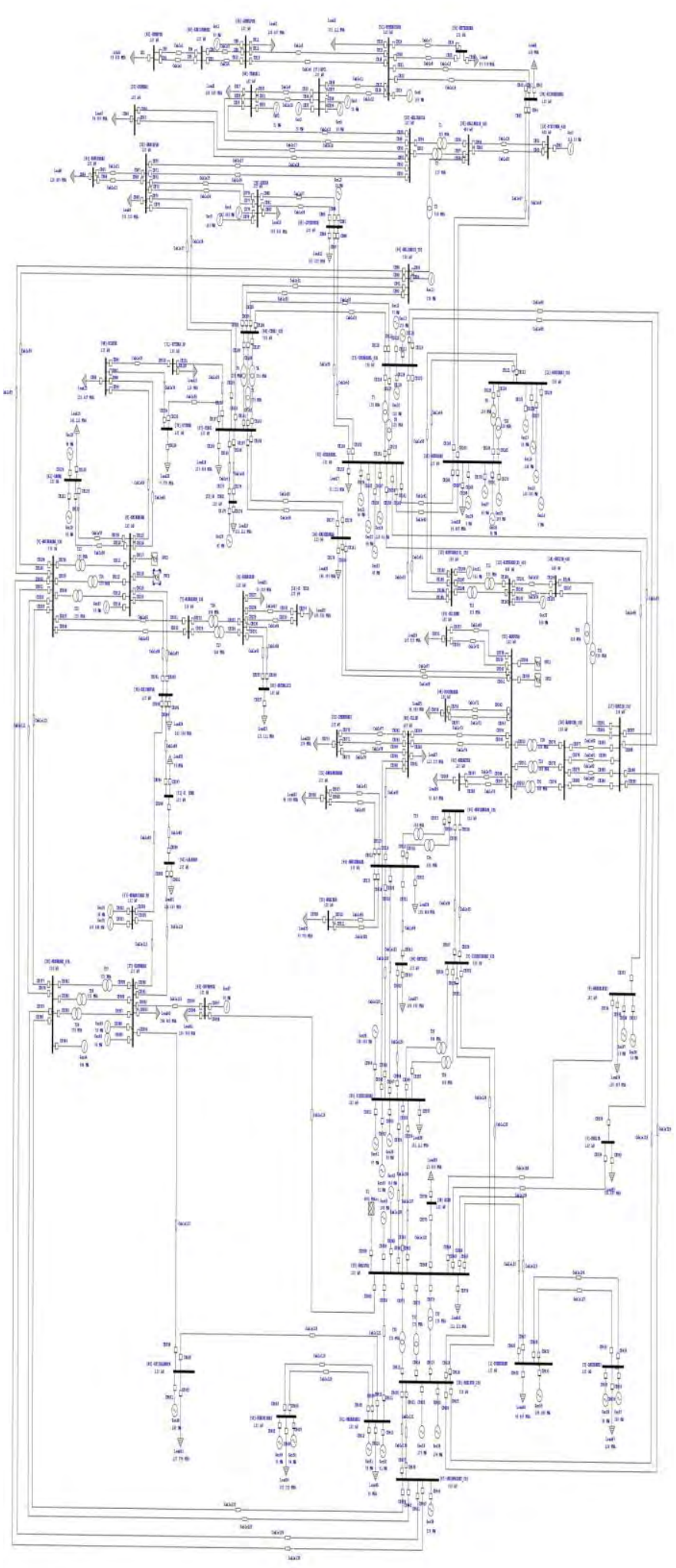

Figure 3. Schematic diagram of Dhaka Grid Circle (using ETAP) 
TABLE I. GENERATION DATA

\begin{tabular}{|c|c|c|c|}
\hline BUS NAME & $\begin{array}{c}\text { ACTIV } \\
\text { E } \\
\text { POWE } \\
\text { R (p.u.) }\end{array}$ & BUS NAME & $\begin{array}{c}\text { ACTIV } \\
\text { E } \\
\text { POWE } \\
\text { R (p.u.) }\end{array}$ \\
\hline JAMALPUR & 0.87 & SAVAR : UNIT-1 & 0.49 \\
\hline TANGAIL & 0.22 & SAVAR : UNIT-2 & 0.55 \\
\hline RPCL : UNIT-1 & 0.20 & AMINBAZAR & 0.68 \\
\hline RPCL : UNIT-2 & 0.20 & $\begin{array}{l}\text { SIDDIRGANJ : } \\
\text { UNIT-1 }\end{array}$ & 1.00 \\
\hline RPCL : UNIT-3 & 0.38 & $\begin{array}{l}\text { SIDDIRGANJ : } \\
\text { UNIT-2 }\end{array}$ & 0.97 \\
\hline MYMENSINGH & 1.85 & $\begin{array}{l}\text { SIDDIRGANJ : } \\
\text { UNIT-3 }\end{array}$ & 0.51 \\
\hline BIBIYANA_400 & 3.10 & $\begin{array}{l}\text { SIDDIRGANJ : } \\
\text { UNIT-4 }\end{array}$ & 0.50 \\
\hline JOYDEVPUR & 0.33 & $\begin{array}{l}\text { NARSHINGDI : } \\
\text { UNIT-1 }\end{array}$ & 0.19 \\
\hline KODDA : UNIT-1 & 1.33 & $\begin{array}{l}\text { NARSHINGDI : } \\
\text { UNIT-2 }\end{array}$ & 0.33 \\
\hline KODDA : UNIT-2 & 1.08 & $\begin{array}{c}\text { KERANIGANJ PP : } \\
\text { UNIT-1 }\end{array}$ & 0.90 \\
\hline KALIAKOIR_230 & 2.00 & $\begin{array}{l}\text { KERANIGANJ PP : } \\
\text { UNIT-2 }\end{array}$ & 1.00 \\
\hline $\begin{array}{l}\text { GHORASHAL_230 : } \\
\text { UNIT-1 }\end{array}$ & 0.75 & HARIPUR : UNIT-1 & 1.05 \\
\hline $\begin{array}{l}\text { GHORASHAL_230: } \\
\text { UNIT-2 }\end{array}$ & 1.20 & HARIPUR : UNIT-2 & 3.86 \\
\hline $\begin{array}{l}\text { GHORASHAL_230: } \\
\text { UNIT-3 }\end{array}$ & 2.10 & $\begin{array}{l}\text { DAUDKANDI : } \\
\text { UNIT-1 }\end{array}$ & 0.48 \\
\hline $\begin{array}{c}\text { ASHUGANJ_230 : } \\
\text { UNIT-1 }\end{array}$ & 0.68 & $\begin{array}{l}\text { DAUDKANDI : } \\
\text { UNIT-2 }\end{array}$ & 2.00 \\
\hline $\begin{array}{l}\text { ASHUGANJ_230: } \\
\text { UNIT-2 }\end{array}$ & 1.00 & SONARGAON & 1 \\
\hline $\begin{array}{l}\text { ASHUGANJ_230: } \\
\text { UNIT-3 }\end{array}$ & 1.30 & $\begin{array}{l}\text { MADANGANJ : } \\
\text { UNIT-1 }\end{array}$ & 0.55 \\
\hline $\begin{array}{l}\text { ASHUGANJ_230 : } \\
\text { UNIT-4 }\end{array}$ & 0.05 & $\begin{array}{l}\text { MADANGANJ : } \\
\text { UNIT-2 }\end{array}$ & 0.81 \\
\hline $\begin{array}{l}\text { GHORASHAL : UNIT- } \\
1\end{array}$ & 0.40 & MEGHNAGHAT_230 & 2.25 \\
\hline $\begin{array}{l}\text { GHORASHAL : UNIT- } \\
2\end{array}$ & 0.34 & MUNSHI : UNIT-1 & 0.35 \\
\hline $\begin{array}{l}\text { GHORASHAL : UNIT- } \\
3\end{array}$ & 0.45 & MUNSHI : UNIT-2 & 0.54 \\
\hline $\begin{array}{l}\text { GHORASHAL : UNIT- } \\
4\end{array}$ & 1.10 & SITALAKHYA & 1.02 \\
\hline ASHUGANJ : UNIT-1 & 0.05 & $\begin{array}{l}\text { HASNABAD : UNIT- } \\
1\end{array}$ & 0.55 \\
\hline ASHUGANJ : UNIT-2 & 0.42 & $\begin{array}{c}\text { HASNABAD : UNIT- } \\
2\end{array}$ & 0.96 \\
\hline ASHUGANJ : UNIT-3 & 0.34 & SHYAMPUR & 0.5 \\
\hline ASHUGANJ : UNIT-4 & 1.50 & HASNABAD_230 & 3.08 \\
\hline ASUGANJ(S)_230 & 3.01 & $\begin{array}{c}\text { HARIPUR 2 } 230: \\
\text { UNIT-1 }\end{array}$ & 1.75 \\
\hline ASUGANJ(N)_400 & 3.60 & $\begin{array}{c}\text { HARIPUR_230: } \\
\text { UNIT-2 }\end{array}$ & 1.74 \\
\hline N. TONGI & 0.42 & $\begin{array}{c}\text { Total Active Power } \\
\text { Generation }\end{array}$ & 59.88 \\
\hline
\end{tabular}

TABLE II. LINE DATA

\begin{tabular}{|c|c|c|c|c|c|c|}
\hline \multirow{2}{*}{$\begin{array}{l}\mathrm{S} \\
\mathrm{L} \\
\mathrm{N} \\
\mathbf{0} \\
\text {. }\end{array}$} & \multirow{2}{*}{$\begin{array}{c}\text { Conductor } \\
\text { Name }\end{array}$} & \multirow[t]{2}{*}{ Size } & \multirow[t]{2}{*}{ Volt } & \multicolumn{3}{|c|}{ Positive Sequence Parameter } \\
\hline & & & & $\begin{array}{c}\text { Resistanc } \\
\text { e } \\
\text { Ohm/km }\end{array}$ & $\begin{array}{c}\text { Reactan } \\
\text { ce } \\
\text { H/km }\end{array}$ & $\begin{array}{c}\text { Suscepta } \\
\text { nce } \\
\text { F/km }\end{array}$ \\
\hline 1 & $\begin{array}{l}\text { GROSBEA } \\
\mathrm{K}\end{array}$ & 636 & 132 & 0.000555 & $\begin{array}{l}0.00235 \\
7\end{array}$ & 0.000493 \\
\hline 2 & AAAC & $\begin{array}{l}37 / 4.176 \\
\text { MM }\end{array}$ & 132 & 0.000555 & $\begin{array}{l}0.00234 \\
8\end{array}$ & 0.000493 \\
\hline 3 & XLPE & $\begin{array}{l}800 \mathrm{MM} \\
\text { SQ }\end{array}$ & 132 & 0.000143 & $\begin{array}{l}0.00063 \\
4\end{array}$ & 0.012376 \\
\hline 4 & MALLARD & 795 & 230 & 0.000145 & $\begin{array}{l}0.00014 \\
5\end{array}$ & 0.000146 \\
\hline 5 & $\begin{array}{l}\text { TWIN } \\
\text { MALLARD }\end{array}$ & $2 \times 795$ & 230 & 0.000072 & $\begin{array}{l}0.00058 \\
6\end{array}$ & 0.001981 \\
\hline 6 & $\begin{array}{l}\text { TWIN } \\
\text { AAAC }\end{array}$ & $\begin{array}{l}37 / 4.176 \\
\text { MM }\end{array}$ & 230 & 0.000073 & $\begin{array}{l}0.00065 \\
8\end{array}$ & 0.001772 \\
\hline 7 & $\begin{array}{l}\text { TWIN } \\
\text { FINCH }\end{array}$ & 1113 & 400 & 0.000018 & $\begin{array}{l}0.00020 \\
6\end{array}$ & 0.005629 \\
\hline 8 & $\begin{array}{l}\text { QUAD } \\
\text { EGRET }\end{array}$ & 636 & 400 & 0.000045 & $\begin{array}{l}0.00052 \\
7\end{array}$ & 0.002226 \\
\hline
\end{tabular}

This table demonstrates the different types of conductors used in Bangladesh Grid Network.

\section{Simulation RESUlts}

Simulation results have been obtained using PSAT 2.1.10 run in MATLAB R2016a and ETAP 16.0.0. All simulations have been done in a computer with Core i5-9400F $2.90 \mathrm{GHz}$ processor, 8.00GB RAM, Windows 10 Pro operating system. Due to the shortage of space it is not possible to accommodate all the data in tabular form. But the necessary data can be recognized from the related graphs.

\section{A. POWER FLOW REPORT FROM PSAT}

Buses:71

Lines: 135

Transformers: 32

Generators: $\quad 32$

Loads: 47

SOLUTION STATISTICS

Number of Iterations: 4

Maximum P mismatch [p.u.] 0

Maximum Q mismatch [p.u.] 0

Power rate [MVA] 
TABLE III. POWER Flow RESUlTS OF SOME RANDOMLy SELECTED Buses of DhaKa GRID CirCle Using NEWTON RAPHSON METHOd (PSAT)

\begin{tabular}{|c|c|c|c|c|c|c|}
\hline Bus Name & $\begin{array}{c}\text { Voltag } \\
\text { e } \\
(\mathrm{kV})\end{array}$ & $\begin{array}{l}\text { Phase } \\
\text { (deg.) }\end{array}$ & $\begin{array}{c}\mathbf{P}_{\text {Gener }} \\
\text { ation } \\
\text { MW }\end{array}$ & $\begin{array}{l}\mathbf{Q}_{\text {Gen }} \\
\text { eration } \\
\text { MVAr }\end{array}$ & $\begin{array}{c}\mathbf{P}_{\text {Load }} \\
\text { MW }\end{array}$ & $\begin{array}{l}\text { Q Load }_{\text {MVAr }} \\
\text { Men }\end{array}$ \\
\hline $\begin{array}{l}{[1]-} \\
\text { SONARGA } \\
\text { ON }\end{array}$ & 132 & 3.4576 & 100 & $\begin{array}{l}13.9 \\
501\end{array}$ & 42 & 20.342 \\
\hline $\begin{array}{l}\text { [2]- } \\
\text { BHULTA }\end{array}$ & $\begin{array}{c}127.34 \\
17 \\
\end{array}$ & -5.1127 & 0 & 0 & 186 & 90.084 \\
\hline $\begin{array}{l}{[30]-} \\
\text { JOYDEVPU } \\
\mathrm{R}\end{array}$ & $\begin{array}{c}138.99 \\
6\end{array}$ & -9.117 & 33 & $\begin{array}{l}134 . \\
9714\end{array}$ & 236 & 114.3 \\
\hline $\begin{array}{l}{[32]-} \\
\text { KABIRPUR }\end{array}$ & $\begin{array}{c}132.90 \\
5\end{array}$ & -9.6798 & 0 & 0 & 209 & 101.223 \\
\hline $\begin{array}{l}{[50]-} \\
\text { MUNSHIGA } \\
\text { NJ }\end{array}$ & $\begin{array}{c}134.99 \\
64\end{array}$ & 0.48673 & 89 & $\begin{array}{r}- \\
630 \\
9082\end{array}$ & 119 & 57.634 \\
\hline $\begin{array}{l}{[51]-} \\
\text { MYMENSIN } \\
\text { GH }\end{array}$ & 130.02 & -23.8682 & 185 & $\begin{array}{c}- \\
160 . \\
3155\end{array}$ & 253 & 122.533 \\
\hline [57]-RPCL & 132 & $\begin{array}{c}- \\
23.5182\end{array}$ & 78 & $\begin{array}{l}352 . \\
8198\end{array}$ & 0 & 0 \\
\hline [58]-RSRM & $\begin{array}{c}131.88 \\
53\end{array}$ & 0.10245 & 0 & 0 & 14 & 6.781 \\
\hline $\begin{array}{l}{[60]-} \\
\text { SATMASJI } \\
\text { D }\end{array}$ & $\begin{array}{c}118.45 \\
04\end{array}$ & -6.2664 & 0 & 0 & 109 & 52.791 \\
\hline [61]-SAVAR & 142.56 & -3.305 & 104 & $\begin{array}{c}318 . \\
5838\end{array}$ & 127 & 61.509 \\
\hline
\end{tabular}

This table contains the details of total 10 buses out of 71 buses.

Global Summary Report

\section{Total Generation}

Real Power [P.U.] 55.432

Reactive Power [P.U.] 33.2171

Total Load

Real Power [P.U.] $\quad 55.25$

Reactive Power [P.U.] 25.3128

Total Losses

Real Power [P.U.] 0.18204

Reactive Power [P.U.] 7.9043

B. POWER FLOW REPORT FROM ETAP

$\begin{array}{lll}\text { Study Case ID } & : & \text { LF } \\ \text { Date Revision } & : & \text { Base } \\ \text { Configuration } & : & \text { Normal } \\ \text { Loading Cat } & : & \text { Design } \\ \text { Generation Cat } & : & \text { Design } \\ \text { Diversity Factor } & : & \text { Normal Loading } \\ \text { Buses } & : & 71 \\ \text { Branches } & : & 167 \\ \text { Generators } & : & 56 \\ \text { Power Grids } & : & 1 \\ \text { Loads } & : & 47 \\ \text { Mismatch-MW } & : & 0 \\ \text { Mismatch-Mvar } & : & 0\end{array}$

TABle IV. Power Flow Results of Some Randomly Selected BUSES OF DHAKA GRID CIRCLE USING ADAPTIVE NEWTON RAPHSON METHOD (ETAP)

\begin{tabular}{|c|c|c|c|c|c|c|}
\hline Bus Name & $\begin{array}{c}\text { Voltag } \\
\text { e } \\
(\mathrm{kV})\end{array}$ & $\begin{array}{l}\text { Phase } \\
\text { (deg.) }\end{array}$ & $\begin{array}{c}\mathbf{P}_{\text {Gener }} \\
\text { ation } \\
\text { MW }\end{array}$ & $\begin{array}{l}\mathbf{Q}_{\mathrm{Gen}} \\
\text { eration } \\
\text { MVAr }\end{array}$ & $\begin{array}{c}\mathbf{P}_{\text {Load }} \\
\text { Mw }\end{array}$ & $\begin{array}{l}\text { Q }_{\text {Load }} \\
\text { MVAr }\end{array}$ \\
\hline $\begin{array}{l}{[1]-} \\
\text { SONARGA } \\
\text { ON }\end{array}$ & 132 & 0.5 & 100 & $\begin{array}{c}- \\
8.96 \\
7\end{array}$ & 42 & 20.342 \\
\hline $\begin{array}{l}\text { 2]- } \\
\text { BHULTA }\end{array}$ & $\begin{array}{c}127.34 \\
17\end{array}$ & -0.3 & 0 & 0 & $\begin{array}{l}182 . \\
930\end{array}$ & 88.597 \\
\hline $\begin{array}{l}\text { [30]- } \\
\text { JOYDEVPU } \\
\text { R }\end{array}$ & $\begin{array}{c}138.99 \\
6\end{array}$ & -0.5 & 33 & 50 & $\begin{array}{c}230 . \\
103\end{array}$ & 111.444 \\
\hline $\begin{array}{l}\text { [32]- } \\
\text { KABIRPUR }\end{array}$ & 132 & -0.5 & 0 & 0 & $\begin{array}{l}203 . \\
105\end{array}$ & 98.378 \\
\hline $\begin{array}{l}{[50]-} \\
\text { MUNSHIGA } \\
\text { NJ }\end{array}$ & 132 & 0 & 89 & $\begin{array}{c}74.2 \\
99\end{array}$ & 119 & 57.634 \\
\hline $\begin{array}{l}{[51]-} \\
\text { MYMENSIN } \\
\text { GH }\end{array}$ & 132 & -1.7 & 185 & 70 & $\begin{array}{l}243 . \\
466\end{array}$ & 117.916 \\
\hline [57]-RPCL & 132 & -1.7 & 78 & 170 & 0 & 0 \\
\hline [58]-RSRM & 132 & 0 & 0 & 0 & $\begin{array}{c}13.9 \\
95\end{array}$ & 6.778 \\
\hline $\begin{array}{l}{[60]-} \\
\text { SATMASJI } \\
\text { D }\end{array}$ & 132 & -0.5 & 0 & 0 & $\begin{array}{l}106 . \\
604\end{array}$ & 51.631 \\
\hline [61]-SAVAR & 132 & -0.5 & 104 & 160 & $\begin{array}{l}125 . \\
961\end{array}$ & 61.006 \\
\hline
\end{tabular}

This table contains the details of total 10 buses out of 71 buses.

$\begin{array}{ll}\begin{array}{l}\text { Global Summary Report } \\ \text { Total Generation }\end{array} \\ \begin{array}{l}\text { Generation-MW } \\ \text { Generation-Mvar }\end{array} & : 5455.118 \\ \text { Total Load } & \\ \text { Load-MW } & : 5455.118 \\ \text { Load-Mvar } & : 2723.603 \\ \text { Total Losses } & : 31.668 \\ \text { Loss-MW } & : 63.823 \\ \text { Loss-Mvar } & \end{array}$

\section{COMPARISON OF SIMULATION RESULTS WITH PGCB BASE CASE DATA}

The simulated results of the voltage magnitudes and phases of the 71 buses in the network were tabulated. In this section we compared the simulated results with PGCB Base Case Data and they are shown in Table V. Table V compares the bus voltage magnitudes obtained from PSAT and ETAP to Base Case data from PGCB, Graphical comparison for all the 71 buses data is shown in Fig. 4. 
TABLE V. COMPARISON OF VOLTAGE MAGNITUdES BETWEEN PSAT, ETAP AND PGCB DATA OF SOME RANDOMLY SELECTED BUSES

\begin{tabular}{|c|c|c|c|}
\hline Bus Name & $\begin{array}{c}\text { Voltage } \\
\text { Magnitude from } \\
\text { PSAT } \\
(\mathbf{k V})\end{array}$ & $\begin{array}{c}\text { Voltage } \\
\text { Magnitude } \\
\text { from } \\
\text { ETAP } \\
(\mathrm{kV})\end{array}$ & $\begin{array}{c}\text { Base Case } \\
\text { Data from } \\
\text { PGCB } \\
(\mathrm{kV})\end{array}$ \\
\hline [ 1]-SONARGAON & 132 & 132 & 132 \\
\hline [2]- BHULTA & 127.3417 & 130.906 & 130 \\
\hline [30]-JOYDEVPUR & 138.996 & 130.319 & 139 \\
\hline [31]-K. CHAR & 128.1551 & 130.187 & 134 \\
\hline [32]-KABIRPUR & 132.905 & 130.096 & 137 \\
\hline [50]-MUNSHI & 134.9964 & 132 & 135 \\
\hline $\begin{array}{l}{[51]-} \\
\text { MYMENSINGH }\end{array}$ & 130.02 & 129.468 & 130 \\
\hline [52]-N. TONGI & 132.99 & 131.014 & 133 \\
\hline [57]-RPCL & 132 & 129.597 & 132 \\
\hline [58]-RSRM & 131.8853 & 131.975 & 132 \\
\hline [59]-SARISHABARI & 133.8082 & 127.979 & 132 \\
\hline [60]-SATMASJID & 118.4504 & 130.437 & 135 \\
\hline [61]-SAVAR & 142.56 & 131.346 & 133 \\
\hline
\end{tabular}

The voltages of all the buses can be observed from the following graph in figure 4 .

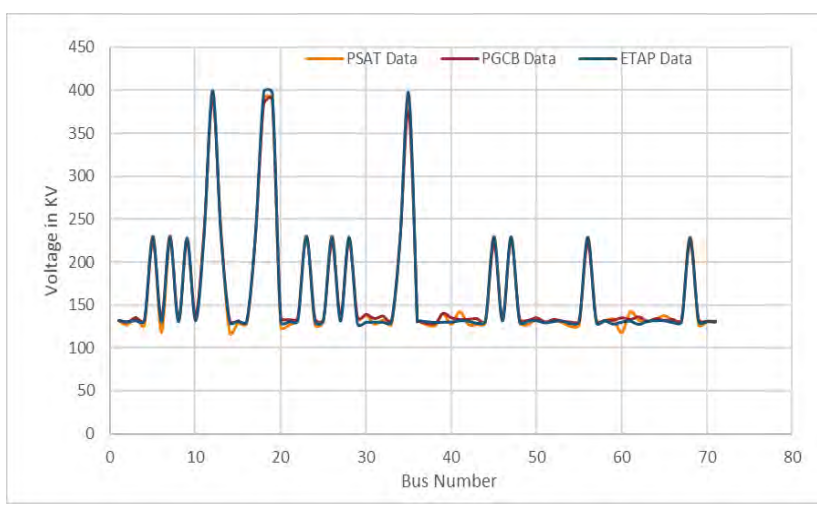

Figure 4. Comparison of Voltages between PSAT, PGCB and ETAP Data.

In this graphical diagram, the voltages of the buses are plotted in the $\mathrm{X}$ axis and the Bus numbers along the $\mathrm{Y}$ axis. It can be observed that the voltages of the simulation results obtained from PSAT and ETAP are very close to that of the PGCB data.

\section{CONCLUSION}

This paper contains the load flow simulation of Dhaka Circle by using the PSAT software is which is an open source toolbox for MATLAB and EPAT software which is a high impact commercial software used worldwide for the design, simulation, operation, and automation of generation, distribution, and industrial power systems. The power flow took a total of 0.39 seconds to complete the simulation for PSAT. The PSAT simulation shows a deviation of around $0.476 \%$ to the Bus Voltages from that of PGCB and the ETAP simulation shows a deviation of about $0.221 \%$ to the Bus Voltages from that of PGCB data due to the reason that the PGCB data is taken for the whole of Bangladesh whereas the data from PSAT and ETAP is only considered for the Dhaka Circle. Moreover, there is a difference of $0.256 \%$ between the voltages of PSAT and ETAP This paper should act as a guideline for the future improvement of power quality as well as introducing a new generator or a new load to the existing model of the Dhaka Grid Circle.

\section{ACKNOWLEDGMENT}

The authors would like to thank Ahmed Mortuza Saleque for providing his valuable guidelines in accomplishing this study work. The authors are also grateful to American International University-Bangladesh and World University of Bangladesh for providing lab facilities.

\section{REFERENCES}

[1] Dharamjit, D.K.Tanti, "Load Flow Analysis on IEEE 30 Bus System" International Journal of Scientific and Research Publications, Volume 2, Issue 11, November 2012

[2] Alexandra Von Meier, Electric Power Systems a Conceptual Introduction, John Wiley \& Sons, Inc., Hoboken, New Jersey, 2006.

[3] Nazia Mehnaz,Asiful Islam Bhuiyan,Manashi Roy,Faruk Hossain, "Load Flow Analysis and Abnormality Removal of Bangladesh Power System Using Software Cyme Psaf ", 2013 IEEE 4th International Conference on Intelligent Systems, Modelling and Simulation, DOI 10.1109/ISMS.2013.88.

[4] M. A. Haque, J. Azadb, J. Rahmanb, "Critical Appreciation of Power System in Bangladesh", Bangladesh J. Sci. Ind. Res. 45(3), 233-242, 2010 .

[5] F. Milano, "An open source power system analysis toolbox", IEEE Trans. on Power Systems, vol. 20, no. 3, pp. 1199-1206, August 2005.

[6] L. Vanfretti, and F. Milano, "Application of the PSAT, an open source software, for educational and research purposes", IEEE Power Engineering Society General Meeting, pp. 1-7, June 2007.

[7] EE Power School Website: https://www.eepowerschool.com/tutorials/etap-for-power-system modeling-simulations/ [Online].

[8] Bangladesh Power Distribution Board Official Website: http://www.bpdb.gov.bd/ [Online]

[9] Power Grid Company of Bangladesh Official Website: http://www.pgcb.org.bd/[Online] 


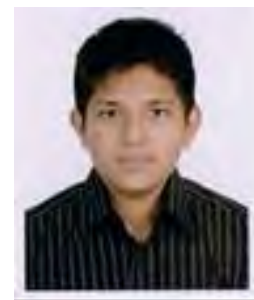

Anas Abdullah Alvi received his B.Sc. in

Electrical and Electronic Engineering degree from American International

University-Bangladesh (AIUB) in 2018. He is currently pursuing M.Sc. in Electrical and

Electronic Engineering degree from

American International UniversityBangladesh (AIUB). He is working as a lecturer in the department of Electrical and Electronic Engineering, World University of Bangladesh since Jan, 2018.

His general research interests are power electronics, power systems and renewable energy.

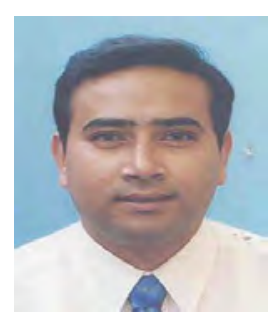

Mohammad Abdul Mannan was born in Laxmipur, Bangladesh on January 01, 1975. $\mathrm{He}$ received his B. Sc. Eng. Degree from Rajshahi University of Engineering and Technology (RUET former BITR), Bangladesh, in 1998, and Masters of Eng. and Dr. of Eng. degrees from Kitami Institute of Technology, Japan, in 2003 and 2006 respectively, all in electrical engineering.

He then joined in the American International University Bangladesh (AIUB) as an Assistant professor on May 2006. Currently he is serving as Professor and Director, EEE Dept. in AIUB. His research interests include electric motor drive, power electronics, power system, wind generation system and control of electric motor, power electronic converters, power system, and wind generation system. 